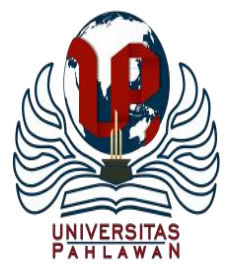

Edukatif : Jurnal Ilmu Pendidikan Volume 3 Nomor 4 Tahun 2021 Halm 2339 - 2350

EDUKATIF: JURNAL ILMU PENDIDIKAN

Research \& Learning in Education

https://edukatif.org/index.php/edukatif/index

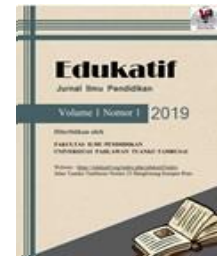

\title{
Penggunaan Media Video Iklan Layanan Masyarakat di Kanal Youtube terhadap Pembelajaran Menulis Paragraf Persuasi Siswa di Sekolah Menengah Pertama
}

\author{
Elbananda Melati Putri ${ }^{1 凶}$, Wienike Dinar Pratiwi ${ }^{2}$, Een Nurhasanah ${ }^{3}$ \\ Universitas Singaperbangsa Karawang, Indonesia ${ }^{1,2,3}$ \\ E-mail : elbanandamelatiput@gmail.com¹ㄴ.wienike.dinar@ fkip.unsika.ac.id ${ }^{2}$, \\ een.nurhasanah@staff.unsika.ac.id ${ }^{3}$
}

\begin{abstract}
Abstrak
Penelitian ini dilatarbelakangi oleh rendahnya nilai siswa dalam keterampilan menulis paragraf persuasi. Tujuan dari penelitian ini yaitu untuk mendeskripsikan penggunaan media video iklan layanan masyarakat dalam pembelajaran menulis paragraf persuasi pada siswa kelas VIII SMP Negeri 3 Cikarang Timur. Metode yang digunakan dalam penelitian ini yaitu metode kuantitatif deskriptif. Dalam penelitian ini terdapat perlakuan berupa media video iklan layanan masyarakat. Populasi yang digunakan dalam penelitian ini adalah kelas VIII di Sekolah Menengah Pertama Negeri 3 Cikarang Timur. Pemilihan sampel menggunakan Sampling Purposive yang disarankan oleh guru bidang studi bersangkutan untuk mengambil sampel pada kelas VIII.6 dengan jumlah siswa 29. Hasil penelitian ini menunjukan bahwa kemampuan siswa dalam menulis teks persuasi memperoleh nilai dengan kategori Baik. Hal tersebut dapat dilihat dari rata-rata nilai siswa setelah mendapatkan perlakuan menggunakan media video iklan layanan masyarakat yaitu 72,27 . Jadi dapat ditarik kesimpulan bahwa terdapat pengaruh yang signifikan pada penggunaan media audio visual terhadap keterampilan menulis paragraf persuasi siswa kelas VIII SMPN 3 Cikarang Timur.

Kata Kunci: Pembelajaran Bahasa Indonesia, Keterampilan Menulis, Media Pembelajaran, Media Audio Visual.
\end{abstract}

\begin{abstract}
This research is motivated by the low score of students in the skill of writing persuasive paragraphs. The purpose of this study is to describe the use of video media for public service advertisements in learning to write persuasive paragraphs for class VIII students of SMP Negeri 3 Cikarang Timur. The method used in this research is descriptive quantitative method. In this study there is a treatment in the form of video media for public service advertisements. The population used in this study was class VIII at State Junior High School 3 Cikarang Timur. The sample selection used purposive sampling which was suggested by the teacher in the field of study concerned to take a sample in class VIII.6 with a total of 29 students. The results of this study showed that the students' ability in writing persuasive texts scored in the Good category. This can be seen from the average value of students after receiving treatment using video media for public service advertisements, which is 72.27. So it can be concluded that there is a significant effect on the use of audiovisual media on the skills of writing persuasive paragraphs for eighth grade students of SMPN 3 Cikarang Timur.
\end{abstract}

Keywords: Indonesian Language Learning, Writing Skills, Learning Media, Audio-Visual Media

Copyright (c) 2021 Elbananda Melati Putri, Wienike Dinar Pratiwi, Een Nurhasanah

$\triangle$ Corresponding author

Email : elbanandamelatiput@gmail.com

DOI : https://doi.org/10.31004/edukatif.v3i4.1183

ISSN 2656-8063 (Media Cetak)

ISSN 2656-8071 (Media Online) 
2340 Penggunaan Media Video Iklan Layanan Masyarakat di Kanal Youtube terhadap Pembelajaran Menulis Paragraf Persuasi Siswa di Sekolah Menengah Pertama - Elbananda Melati Putri, Wienike Dinar Pratiwi, Een Nurhasanah

DOI: https://doi.org/10.31004/edukatif.v3i4.1183

\section{PENDAHULUAN}

Bahasa merupakan salah satu bagian terpenting dalam kehidupan manusia. Manusia tidak akan pernah terlepas dari bahasa karena pada dasarnya bahasa merupakan alat komunikasi yang digunakan manusia. Menurut (Pringgawidagda 2002:4) bahasa merupakan alat utama untuk berkomunikasi dalam kehidupan manusia, baik secara individu maupun kolektif sosial. (Chaer dan Agustina 1955:14) berpendapat bahwa fungsi utama bahasa adalah sebagai alat komunikasi. Hal ini sejalan dengan pendapat (Soeparno 1993:5) yang menyatakan bahwa fungsi umum bahasa adalah sebagai alat komunikasi sosial. Dari beberapa pendapat di atas, maka penulis simpulkan bahasa merupakan alat komunikasi yang digunakan oleh manusia dengan memanfaatkan bunyi ataupun lambang sebagai medianya.

Pada hakikatnya pembelajaran bahasa yaitu belajar untuk berkomunikasi dengan baik. Oleh karena itu, pembelajaran bahasa diarahkan untuk meningkatkan kemampuan siswa dalam berkomunikasi dengan Bahasa Indonesia baik lisan maupun tulisan. Dalam pembelajaran bahasa terdapat 4 keterampilan yang harus dikuasai oleh siswa yaitu diantaranya keterampilan menyimak, keterampilan berbicara, keterampilan membaca, dan keterampilan menulis. Setiap keterampilan saling memiliki keterkaitan antara satu dengan keterampilan lainnya.

Menurut (Fitriyana 2011) menulis menggambarkan suatu kegiatan yang bermanfaat dan ekspresif. menulis merupakan suatu keterampilan berbahasa yang dipergunakan untuk berkomunikasi secara tidak langsung, tidak secara tatap muka dengan orang lain. Menurut (Tarigan 2017:22) Menulis ialah menurunkan atau melukiskan lambang-lambang grafik yang menggambarkan suatu bahasa yang dipahami oleh seseorang sehingga orang lain dapat membaca lambang-lambang grafis tersebut kalau mereka memahami bahasa dan gambaran grafik itu. Selain itu (Dalman 2014:3) mengemukakan bahwa menulis merupakan sebuah proses kreatif menuangkan gagasan dalam bentuk bahasa tulis dalam tujuan, misalnya, memberitahu, menyakinkan, atau menghibur. Hasil dari proses kreatif ini biasa disebut dengan karangan atau tulisan. Menurut (Sari 2020) Menulis yaitu sebagai alat perantara dari gagasan yang masih ada diotak dengan penuangan dalam bentuk tulisan. Sedangkan menurut (Br. Sebayang and Kristina n.d.) Fungsi dan tujuan menulis yaitu sebagai alat komunikasi secara tidak langsung dan tujuan menulis adalah memberi informasi, meyakinkan dari apa yang dipikirkan dan dirasakan kepada orang lain. Dari pemaparan di atas, dapat penulis simpulkan menulis adalah proses menuangkan pikiran dan perasaan dapat berupa lambang-lambang grafis yang dikembangkan dan dituangkan dalam bentuk tulisan. Dengan demikian, melalui kegiatan menulis seseorang akan dapat mengembangkan, mengekspresikan pikiran, gagasan, perasaan, dan pengalaman kepada orang lain.

Kegiatan menulis yaitu suatu kegiatan yang tidak bisa terpisahkan dalam seluruh proses belajar siswa di kelas. Selama menuntut ilmu di sekolah, siswa sering diajarkan dan diberi tugas untuk menulis suatu teks, oleh karena itu mereka diharapkan akan mempunyai wawasan yang lebih luas dan mendalam setelah melakukan kegiatan menulis. Menulis secara umum juga dapat diartikan sebagai suatu kegiatan penyampaian pesan atau komunikasi dengan menggunakan bahasa tulis sebagai alat atau medianya. Menurut (Famela 2014) Keterampilan menulis merupakan keterampilan yang paling akhir, yaitu seseorang yang telah melakukan proses belajar keterampilan berbahasa maka diharuskan mampu untuk menulis atau menuangkan pemahamannya dalam bentuk tulisan maka keterampilan menulis ini sangatlah penting untuk dikuasai oleh siswa. Oleh karena itu keterampilan menulis tidak langsung datang dan dapat dikuasai. Karena dalam penerapan keterampilan menulis melibatkan keterampilan berbahasa yang lain, yaitu keterampilan membaca. Seseorang akan lebih mudah menulis apabila sering membaca. Kebiasaan membaca dapat memperluas pengetahuan, wawasan dan kosakata yang kita miliki. Hal ini sejalan dengan pendapat (Partawan, Putrayasa, and Sriasih n.d.) Menulis merupakan salah satu dari empat keterampilan berbahasa yang tidak dapat dipisahkan dalam seluruh proses pembelajaran di satuan pendidikan, mulai dari satuan pendidikan dasar 
2341 Penggunaan Media Video Iklan Layanan Masyarakat di Kanal Youtube terhadap Pembelajaran Menulis Paragraf Persuasi Siswa di Sekolah Menengah Pertama - Elbananda Melati Putri, Wienike Dinar Pratiwi, Een Nurhasanah

DOI: https://doi.org/10.31004/edukatif.v3i4.1183

hingga perguruan tinggi. Kemampuan menulis tidak datang dengan sendirinya, tetapi memerlukan latihan yang bersungguh-sungguh dan terus menerus. Saat ini keterampilan menulis menjadi salah satu keterampilan Bahasa Indonesia yang masih terdapat masalah di dalam pembelajarannya khususnya di jenjang Sekolah Menengah Pertama (SMP). Hal ini membuat pembelajaran menulis kurang di minati oleh kalangan siswa yang mengakibatkan rendahnya nilai siswa dalam hal kepenulisan. Salah satu keterampilan menulis dalam pembelajaran bahasa Indonesia di sekolah yaitu menulis teks persuasi.

Dalam kurikulum 2013, menulis teks persuasi adalah salah satu kompetensi yang harus dikuasai oleh peserta didik kelas VIII tingkat Sekolah Menengah Pertama (SMP). Persuasi merupakan salah satu jenis tulisan yang isinya berupa suatu ajakan. (Aliyah 1994) berpendapat bahwa kemampuan menulis paragraf persuasi pada dasarnya harus mampu mengutarakan ide, perasaan, pikiran, dan kemampuannya kepada orang lain melalui tulisan agar pembaca yakin dengan apa yang dilakukan sesuai khenak penulis. Menurut (Sasongko, Yulianti, and Karsono 2008) Karangan persuasi bertujuan untuk menyampaikan informasi yang mampu menarik perhatian pembacanya dan mengajak pembaca untuk meyakini dan menuruti himbauan penulis. Artinya karangan persuasi berhubungan dengan masalah mempengaruhi orang lain lewat bahasa tulis. Berdasarkan penjelasan di atas, dapat penulis simpulkan bahwa menulis paragraf persuasi adalah keterampilan menyampaikan gagasan melalui tulisan yang berisi ajakan kepada seseorang dengan cara memberikan alasan dan prospek baik yang meyakinkannya. Artinya, dengan menulis paragraf persuasi siswa akan menjadi tanggap dan peka terhadap kondisi dan situasi lingkungan di sekitarnya. Namun, dalam pembelajaran menulis paragraf persuasi masih memiliki hambatan yang menyebabkan rendahnya nilai keterampilan menulis paragraf persuasi siswa. Penelitian ini dilaksanakan di Sekolah Menengah Pertama Negeri 3 Cikarang Timur. Penulis memilih sekolah tersebut karena di Sekolah Menengah Pertama Negeri 3 Cikarang Timur masih terdapat beberapa kendala dalam pembelajaran teks persuasi.

Sesuai dengan hasil observasi yang telah dilakukan, nilai pembelajaran menulis paragraf persuasi di Sekolah Menengah Pertama Negeri 3 Cikarang Timur masih rendah. Hal ini dikarenakan pembelajaran menulis paragraf persuasi tersebut memiliki masalah pada aspek kesesuaian isi dan strukturnya. Siswa masih belum mampu mengutarakan apa yang akan menjadi objek kepenulisannya. Selain itu siswa juga masih belum mampu menuliskan paragraf persuasi dengan stuktur yang lengkap. Menurut (Suwandi 2018) Untuk dapat membelajarkan bahasa dan sasatra Indonesia dengan menggunakan pembelajaran campuran, seorang guru perlu memiliki pengetahuan teknologi (technological knowledge), yakni pengetahuan tentang bagaimana menggunakan hardware dan software dan menghubungkan antara keduanya. Oleh karena itu, harus adanya inovasi baru dalam pembelajaran menulis paragraf persuasi. Salah satu inovasi dalam proses kegiatan belajar mengajar yaitu dengan memanfaatkan media pembelajaran. Media pembelajaran adalah segala sesuatu yang dapat menyampaikan dan menyalurkan pesan dari sumber secara terencana sehingga tercipta lingkungan belajar yang kondusif dimana penerimanya dapat melakukan proses belajar secara efisien dan efektif (Munadi 2008:7-8). (Hamid, dkk. 2020:4) berpendapat bahwa media pembelajaran yaitu segala sesuatu yang dapat menyampaikan pesan melalui berbagai saluran, dapat merangsang pikiran, perasaan, dan kemauan siswa sehingga dapat mendorong terciptanya proses belajar untuk menambah informasi baru pada diri siswa sehingga tujuan pembelajaran dapat tercipta dengan baik. Menurut (Arsyad 2002:12) Media pembelajaran adalah sebuah alat yang berfungsi untuk menyampaikan pesan pembelajaran. Dari pemaparan di atas, dapat penulis simpulkan media pembelajaran merupakan alat, bahan dan segala sesuatu yang dapat menyalurkan pesan atau informasi pembelajaran kepada siswa, sehingga pembelajaran dapat berlangsung secara efektif dan efisien.

Media pembelajaran dapat berfugsi sebagai jembatan untuk menghubungkan atau menyalurkan informasi dari guru kepada peserta didik dengan cara yang lebih menyenangkan. Media pembelajaran memiliki peran penting dalam kegiatan pembelajaran, karena dengan penggunaan media yang tepat dapat 
menarik perhatian siswa. Hal ini akan membuat siswa lebih berantusias dalam mengikuti pembelajaran dan semangat untuk memahami materi yang disampaikan. Tujuan tersebut sejalan dengan pendapat (Astuti, Arifin, and Trianto n.d.) yaitu penggunaan media dirasa perlu untuk menarik perhatian siswa serta dapat merangsang siswa lebih kreatif sehingga nantinya dapat meningkatkan hasil belajar. Beberapa psikolog memandang bahwa media komunikasi antar manusia yang paling mendominasi adalah pancaindera seperti mata dan telinga. Pesan-pesan yang ditangkap oleh pancaindera manusia, akan di proses oleh pikiran untuk mengontrol dan menentukan sikap terhadap sesuatu sebelum bertindak. Oleh karena itu dalam penelitian ini, penulis menerapkan media audio visual yaitu video iklan layanan masyarakat yang ada di kanal youtube untuk pembelajaran menulis paragraf persuasi. Penerapan media video ini dilakukan agar dapat memberikan respon yang lebih aktif dari siswa terhadap pembelajaran menulis paragraf persuasi. Sehingga pembelajaran tersebut dapat berkesan bagi para siswa dan siswa tidak lagi merasa pembelajaran menulis paragraf persuasi itu sulit.

Media audio visual merupakan media yang dimanfaatkan sebagai perantara guru kepada siswa dalam menyampaikan tujuan pembelajaran yang menggunakan indra penglihatan dan indra pendengaran. Menurut (Mulyani and Syahrul 1967) Media audiovisual merupakan alat untuk merangsang daya pikir siswa dalam menemukan suatu ide pokok sehingga dapat menuliskannya ke dalam sebuah teks persuasi yang utuh. Menurut (Nana Sudjana dan Ahmad Rivai 2003:58) media audio visual adalah media penyalur pesan dengan memanfaatkan indra pendengaran dan penglihatan. Menurut (Ribawati 2015) Penggunaan video akan menimbulkan motivasi belajar siswa, motivasi belajar siswa akan nampak dalam aktivitas siswa tersebut dalam belajar yang pada akhirnya dapat menimbulkan hasil belajar siswa yang optimal. Pendapat tersebut sejalan dengan (Rusmiyati, Nurkamto, and Haryanto 2014) yang mengatakan bahwa multimedia memberikan dampak positif bagi pemahaman materi masingmasing peserta didik. Peserta didik tidak lagi berpikir abstrak, dengan adanya multimedia yang digunakan guru di kelas. Dapat disimpulkan bahwa media audio visual merupakan media perantara dalam penyampaian materi pembelajaran yang penyerapannya melalui pandangan dan pendengaran sehingga membangun kondisi yang dapat membuat siswa mampu memperoleh pengetahuan, keterampilan, atau sikap dengan cara yang lebih bervariatif.

Ada beberapa kelebihan dari media audio visual, (Daryanto 2013:90) mengatakan bahwa keuntungan menggunakan media video antara lain: 1) ukuran tampilan video sangat fleksibel dan dapat diatur sesuai dengan kebutuhan; 2) video merupakan bahan ajar non cetak yang kaya akan informasi dan lugas karena dapat sampai kehadapan siswa secara langsung; 3) video menambah suatu dimensi baru terhadap pembelajaran. Dengan kelebihan-kelebihan yang telah diuraikan di atas, penulis memutuskan untuk menggunakan media audio visual dengan harapan dapat memberikan kesan belajar yang menyenangkan dan menarik minat serta gairah siswa dalam menulis paragraf persuasi. Adapun tujuan dari penelitian ini yaitu untuk mendeskripsikan penggunaan media video iklan layanan masyarakat terhadap keterampilan menulis paragraf persuasi di Sekolah Menengah Pertama khususnya di Sekolah Menengah Pertama Negeri 3 Cikarang Timur. Penelitian ini akan mendeskripsikan apakah dengan adanya bantuan media, nilai paragraf persuasi siswa akan meningkat daripada pembelajaran sebelum menggunakan bantuan media.

Pada pembelajaran menulis paragraf persuasi, penulis akan meminta peserta didik untuk membuat sebuah paragraf persuasi. Setelah itu penulis akan menjelaskan materi mengenai paragraph lalu menyajikan sebuah video iklan layanan masyarakat dari aplikasi youtube kepada peserta didik. Namun dikarenakan situasi saat ini sedang maraknya wabah virus covid-19, maka pemberian media video dilakukan dengan memanfaatkan website yang telah disediakan oleh Sekolah Menengah Pertama Negeri 3 Cikarang Timur. Penulis akan menyajikan video tersebut ke dalam google drive lalu di cantumkan ke dalam website sekolah dan disertakan dengan arahan tugas menulis paragraf persuasi. Peserta didik dapat menulis paragraf persuasi sesuai dengan video yang disajikan. Diharapkan dengan adanya media video iklan layanan masyarakat ini mampu memberikan pembelajaran yang efektif dan mudah dipahami oleh peserta didik. 
Adapun penelitian yang relevan dengan penelitian ini, yaitu penelitian yang dilakukan oleh Dina Apriana pada tahun 2009 tentang Peningkatan Keterampilan Menulis Poster Dengan Media Iklan Layanan Masyarakat Di Televisi Siswa Kelas VIII C SMP Negeri 4 Cilacap. Persamaan dari penelitian tersebut yaitu sama-sama menggunakan media video iklan layanan masyarakat. Perbedaannya yaitu penelitian yang dilakukan oleh Dina Apriana menggunakan media tersebut untuk meneliti keterampilan menulis poster, sedangkan penelitian ini menggunakan media untuk meneliti keterampilan menulis paragraf persuasi siswa. Penelitian yang dilakukan oleh Dina Apriana merupakan Penelitian Tindakan Kelas (PTK) yang harus dilakukan dalam beberapa siklus. Sedang penelitan ini merupakan penelitian eksperimen yang dilakukan menggunakan metode pre-experimental desains. Selain itu penelitian yang dilakukan oleh Dina Apriana merupakan penelitian offline atau tatap muka, sedangkan penelitian ini dilakukan penulis secara online dengan bantuan website sekolah.

\section{METODE PENELITIAN}

Pada penelitian ini penulis menggunakan pendekatan kuantitatif karena data-data disajikan berupa angka dan dianalisis menggunakan bentuk statis. Metode yang digunakan yaitu metode pre-experimental desain. Menurut (Sugiyono 2017) konsep dari metode penelitian eksperimen yaitu metode yang digunakan untuk mencari pengaruh perlakuan tertentu terhadap yang lain dalam kondisi yang terkendali. Dalam penelitian ini adapun perlakuan berupa media video iklan masyarakat yang diuji cobakan pada tes akhir (posttest). Siswa akan diberikan test awal (pre-test) yaitu menulis paragraph persuasi sebelum diberikan perlakuan, lalu siswa akan diberikan perlakuan dan diakhiri dengan melakukan tes akhir (post-test) menulis paragraf persuasi setelah diberikan perlakuan.

Menurut (Djaali : 2020) populasi adalah keseluruhan unit analisis yang akan diselidiki atau dipelajari karakteristiknya. Populasi dalam penelitian ini adalah seluruh kelas VIII di Sekolah Menengah Pertama Negeri 3 Cikarang Timur. Jumlah siswa keseluruhan di kelas VIII sebanyak 242 siswa dengan jumlah kelas sebanyak 7 kelas.

Menurut (Sugiyono 2017) sampel merupakan jumlah dan karakteristik yang dimiliki oleh populasi tersebut. Pemilihan sampel menggunakan Sampling Purposive. Pemilihan sample dilakukan saran dari guru bidang studi yang bersangkutan untuk mengambil sampel pada kelas VIII.6 dengan jumlah siswa 29.

Desain penelitian ini menggunakan one-group pretest-posttest design. Terdapat 1 kelas yang dipilih, $\mathrm{O} 1$ merupakan nilai pretest, variable $\mathrm{X}$ merupakan perlakuan yang akan dilakukan pada $\mathrm{O} 2$ yaitu nilai posttest, perlakuan tersebut berupa media yang akan diterapkan pada siswa.

\begin{tabular}{c|c|c}
\hline $\mathrm{O}^{1}$ & $\mathrm{X}$ & $0^{2}$ \\
\hline \multicolumn{2}{l}{ Sumber: (Sugiyono 2017) }
\end{tabular}

Teknik pengumpulan data yang digunakan pada penelitian ini yaitu teknik tes. Tes tersebut digunakan untuk memperoleh data hasil penelitian mengenai keterampilan menulis paragraf persuasi. Instrumen tes dalam penelitian ini digunakan peneliti sebagai teknik pengumpulan data utama, karena tujuan utama pada penelitian ini adalah untuk mendeskripsikan keefektifan media video. Instrumen tes dapat diartikan sebagai alat yang dipergunakan untuk mengukur pengetahuan atau penguasaan objek ukur, sebagai unit analisis penelitian terhadap seperangkat konten atau materi tertentu (Djaali 2020:60). Instrumen tes yang digunakan dalam penelitian ini yaitu berupa tes menulis paragraf persuasi untuk tes awal dan tes akhir. Berikut bentuk soal uraian yang akan digunakan: 
Tabel 1. Instrumen Test Awal

Petunjuk:

\section{TES AWAL MENULIS PARAGRAF PERSUASI}

1. Tulislah nama beserta kelas sebagai identitas diri.

2. Buatlah sebuah 2344aragraph persuasi dengan tema bebas.

3. Setelah selesai mengerjakan, silahkan upload pada website sekolah.

Tabel 2. Instrumen Test Akhir

\section{TES AKHIR MENULIS PARAGRAF PERSUASI}

Petunjuk:

1. Tulislah nama beserta kelas sebagai identitas diri.

2. Buatlah sebuah paragraf persuasi sesuai dengan informasi di dalam video iklan layanan masyarakat yang sudah di berikan.

3. Setelah selesai mengerjakan, silahkan upload pada website sekolah.

Selanjutnya, hasil menulis paragraf persuasi siswa diberikan penilaian. Peneliti memiliki pedoman penilaian yang digunakan dalam penelitian ini. berikut aspek penilaian yang digunakan untuk mengetahui nilai hasil menulis siswa:

Tabel 3. Instrumen Penilaian

\begin{tabular}{|c|c|c|}
\hline $\begin{array}{l}\text { Aspek yang } \\
\text { dinilai }\end{array}$ & Kriteria & Skor \\
\hline \multirow{5}{*}{ Kesesuaian Isi } & $\begin{array}{l}\text { Isi teks yang disampaikan lengkap (mengandung } \\
\text { argumen, fakta, dan ajakan), informasi yang } \\
\text { disampaikan rinci atau banyak dan sesuai }\end{array}$ & 5 \\
\hline & $\begin{array}{l}\text { Isi teks yang disampaikan lengkap (mengandung } \\
\text { argumen, fakta, dan ajakan), informasi yang } \\
\text { disampaikan kurang rinci atau sedikit, namun } \\
\text { masih sesuai }\end{array}$ & 4 \\
\hline & $\begin{array}{l}\text { Isi teks yang disampaikan lengkap, tetapi } \\
\text { informasi yang disampaikan kurang rinci dan } \\
\text { cukup sesuai }\end{array}$ & 3 \\
\hline & $\begin{array}{l}\text { Isi teks yang disampaikan kurang lengkap, } \\
\text { informasi yang disampaikan kurang rinci atau } \\
\text { sangat sedikit dan kurang sesuai }\end{array}$ & 2 \\
\hline & $\begin{array}{l}\text { Isi teks yang disampaikan tidak lengkap (tidak } \\
\text { mengandung argumen, fakta, dan ajakan), } \\
\text { informasi yang disampaikan sangat sedikit dan } \\
\text { tidak sesuai }\end{array}$ & 1 \\
\hline \multirow[t]{2}{*}{$\begin{array}{l}\text { Kelengkapan } \\
\text { Struktur Teks }\end{array}$} & $\begin{array}{l}\text { Struktur teks yang disampaikan lengkap } \\
\text { (Pengenalan isu, Rangkaian Argumen, } \\
\text { Pernyataan ajakan, dan Penegasan Ulang), dan } \\
\text { disusun secara sistematis. }\end{array}$ & 5 \\
\hline & $\begin{array}{l}\text { Struktur teks yang disampaikan lengkap, tapi } \\
\text { urutannya tidak sistematis, namun masih sesuai }\end{array}$ & 4 \\
\hline
\end{tabular}


2345 Penggunaan Media Video Iklan Layanan Masyarakat di Kanal Youtube terhadap Pembelajaran Menulis Paragraf Persuasi Siswa di Sekolah Menengah Pertama - Elbananda Melati Putri, Wienike Dinar Pratiwi, Een Nurhasanah

DOI: https://doi.org/10.31004/edukatif.v3i4.1183

\begin{tabular}{clc}
\hline & $\begin{array}{l}\text { Struktur teks yang disampaikan lengkap, namun } \\
\text { urutannya tidak sistematis, cukup sesuai }\end{array}$ & 3 \\
\cline { 2 - 3 } & $\begin{array}{l}\text { Struktur teks yang disampaikan kurang lengkap, } \\
\text { urutannya tidak sistematis, dan kurang sesuai }\end{array}$ & 2 \\
\hline & Struktur teks yang disampaikan tidak lengkap & 1 \\
\hline & $\begin{array}{l}\text { Tidak terdapat kesalahan ejaan dan tata tulis } \\
\text { Kesalahan ejaan dan tata tulis sebanyak 1-6 } \\
\text { kesalahan }\end{array}$ & 4 \\
\cline { 2 - 3 } $\begin{array}{l}\text { Ejaan dan Tata } \\
\text { Tulis }\end{array}$ & $\begin{array}{l}\text { Kesalahan ejaan dan tata tulis sebanyak 7-13 } \\
\text { kesalahan }\end{array}$ & 3 \\
\cline { 2 - 3 } & $\begin{array}{l}\text { Kesalahan ejaan dan tata tulis sebanyak 14-20 } \\
\text { kesalahan }\end{array}$ & 2 \\
\cline { 2 - 3 } & $\begin{array}{l}\text { Kesalahan ejaan dan tata tulis lebih atau sama } \\
\text { dengan 20 kesalahan }\end{array}$ & 1 \\
\hline Modifikasi Nurgiyantoro 2010,487)
\end{tabular}

Tabel 4. Aspek Penilaian

\begin{tabular}{ccc}
\hline No & Aspek Yang Dinilai & Skor \\
\hline 1. & Kesesuaiam Isi & 5 \\
\hline 2. & Kelengkapan Struktur & 5 \\
\hline 3. & Ejaan dan Tata Bahasa & 5 \\
\hline & Jumlah Skor & $\mathbf{1 5}$ \\
\hline
\end{tabular}

Tabel 5. Interval Nilai

\begin{tabular}{ccc}
\hline No. & Interval Nilai & Keterangan \\
\hline 1. & $85-100$ & Baik Sekali \\
\hline 2. & $69-84$ & Baik \\
\hline 3. & $53-68$ & Cukup \\
\hline 4. & $37-52$ & Kurang \\
\hline 5. & $21-36$ & Kurang Sekali \\
\hline \multicolumn{2}{l}{ Sumber (Nurgiyantoro 2016) }
\end{tabular}

Analisis data dapat diartikan sebagai upaya mengolah data menjadi informasi sehingga karakteristik dan sifat-sifat data tersebut dapat dengan mudah dipahami dan bermanfaat untuk menjawab masalah-masalah yang berkaitan dengan penelitian. Teknik analisis data yang digunakan yaitu analisis data statistik deskriptif. Penulis memilih analisis data statistik deskriptif karena ingin mendeskripsikan data yang diambil dari sampel. Analisis ini digunakan untuk menghitung nilai hasil rata-rata dan data statistik yang diperoleh pada pre-test (sebelum diberikan perlakuan) dan post-test (sesudah diberikan perlakuan). Hal ini digunakan untuk melihat perbandingan hasil keterampilan menulis paragraf persuasi sebelum diberikan perlakuan dengan sesudah diberikan perlakuan. Analisis data statistic deskriptif yang digunakan yaitu uji-t, tetapi sebelumnya dilakukan uji normalitas sebagai syarat dapat dilaksanakannya analisis data.

1. Uji Normalitas

Uji normalitas bertujuan untuk mengetahui apakah data yang bersangkutan berdistribusi normal atau tidak. Uji normalitas merupakan analisis statistik yang pertama kali dilakukan dalam analisis data. Analisis data dapat dilanjutkan apabila data berdistrbusi normal. Pengujian menggunakan uji Kolmogorov-Smirnov. Data penelitian dikatakan menyebar dengan normal apabila signifikansi atau nilai probabilitas $>0,05$. 
2346 Penggunaan Media Video Iklan Layanan Masyarakat di Kanal Youtube terhadap Pembelajaran Menulis Paragraf Persuasi Siswa di Sekolah Menengah Pertama - Elbananda Melati Putri, Wienike Dinar Pratiwi, Een Nurhasanah

DOI: https://doi.org/10.31004/edukatif.v3i4.1183

2. Uji Hipotesis

Setelah melakukan uji normalitas, langkah selanjutnya adalah melakukan uji hipotesis dengan menggunakan uji T-test. Uji hipotesis ini digunakan untuk mengetahui adanya pengaruh penggunaan media audio visual terhadap keterampilan menulis paragraph persuasi siswa dibandingkan dengan keterampilan menulis paragraph persuasi siswa tanpa penggunaan media. Dalam pengujian ini, peneliti menggunakan program SPSS 22 yaitu dengan teknik analisis Paired-Sample T-Test. Uji hipotesis dilakukan untuk mengetahui apakah terdapat perbedaan rata-rata secara sinifikan antara hasil pre-test dengan hasil post-test.

\section{HASIL DAN PEMBAHASAN PENELITIAN}

Pada bagian ini akan dideskripsikan hasil penelitian penggunaan media video iklan layanan masyarakat di kanal youtube terhadap pembelajaran menulis paragraf persuasi siswa kelas VIII di Sekolah Menengah Pertama Negeri 3 Cikarang Timur. Penelitian ini menggunakan metode kuantitatif. Hasil dari kuantitatif berupa angka-angka. Oleh karena itu hasil dari penelitian ini dinyatakan dalam bentuk angka untuk mengetahui kemampuan rata-rata siswa dalam menulis paragraph persuasi yang ditinjau dari kesesuaian isi, kelengkapan stuktur dan kepenulisannya. Berikut rinciannya:

\section{Pengujian Normalitas}

Uji normalitas dilakukan untuk mengetahui apakah data berdistribusi normal. Perhitungan uji normalitas data dalam penelitian ini mengunakan uji kolmogorov-smirnov test dengan program SPSS versi 22. Data penelitian dikatakan menyebar dengan normal apabila nilai kolmogorov-smirnov test $>0,05$. Data penelitian yang diuji yakni nilai kemampuan menulis paragraph persuasi siswa kelas 8.6 SMPN 3 Cikarang Timur.

Tabel 6. Tests of Normality

\begin{tabular}{lcccr}
\hline & \multicolumn{4}{c}{ Kolmogorov-Smirnov $^{\mathrm{a}}$} \\
\cline { 2 - 5 } & Statistic & Df & Sig. \\
\hline Pre-test & .157 & 29 & $\mathbf{0 6 4}$ \\
\hline Post-test & .155 & 29 & $\mathbf{0 7 2}$ \\
\hline
\end{tabular}

Berdasarkan hasil uji normalitas menggunakan uji kolmogorov-smirnov test di atas dapat disimpulkan sebagai berikut:

a. Nilai pre-test dihasilkan nilai Sig $>\alpha$ yaitu $0,064>0,05$ sehingga nilai prates berdistribusi normal.

b. Nilai post-test dihasilkan nilai Sig $>\alpha$ yaitu $0,72>0,05$ sehingga nilai pascates kelompok eksperimen berdistribusi normal.

Perbandingan Rata-rata Nilai Menulis Paragraf Persuasi pada Siswa yang Diajar Tanpa Menggunakan Media Video dengan Nilai Menulis Paragraf Persuasi yang Diajar Menggunakan Media Video.

Berikut perbandingan rata-rata nilai hasil menulis paragraf persuasi tanpa menggunakan media video yang didapat dari nilai pre-test dengan hasil post-test yang merupakan hasil keterampilan menulis paragraf persuasi menggunakan media video.

Tabel 7. Perbandingan Rata-Rata Nilai Hasil Pre-Test dengan Post-test

\begin{tabular}{llrr}
\hline & & Pre-Test & \multicolumn{2}{r}{ Post-Test } \\
\hline N & Valid & 29 & 29 \\
\cline { 2 - 4 } & Missing & 0 & 0 \\
\hline Mean & & 62.83 & 72.17 \\
\hline
\end{tabular}


2347 Penggunaan Media Video Iklan Layanan Masyarakat di Kanal Youtube terhadap Pembelajaran Menulis Paragraf Persuasi Siswa di Sekolah Menengah Pertama - Elbananda Melati Putri, Wienike Dinar Pratiwi, Een Nurhasanah

DOI: https://doi.org/10.31004/edukatif.v3i4.1183

\begin{tabular}{lrr}
\hline Median & 67.00 & 73.00 \\
\hline Mode & 67 & 73 \\
\hline Minimum & 47 & 60 \\
\hline Maximum & 87 & 93 \\
\hline Sum & 1822 & 2093 \\
\hline
\end{tabular}

Berdasarkan tabel di atas, rata-rata nilai siswa yang telah diberikan perlakuan (treatment) lebih tinggi dari pada rata-rata nilai siswa yang diajar tanpa perlakuan (treatment), yakni 72,18 dengan 62,83.

Tabel 8. Pebandingan persentase pre-test dengan post-test siswa yang mampu menulis paragraf Persuasi ditinjau dari aspek penilaian

\begin{tabular}{lrrrr}
\hline $\begin{array}{l}\text { Aspek } \\
\text { Penilaian }\end{array}$ & $\begin{array}{l}\text { Frekuensi } \\
\text { Pretest }\end{array}$ & Presentase & $\begin{array}{l}\text { Frekuensi } \\
\text { Posttest }\end{array}$ & Persentase \\
\hline $\begin{array}{l}\text { Kesesuaian } \\
\text { Isi }\end{array}$ & 18 & $62 \%$ & 24 & $82 \%$ \\
\hline $\begin{array}{l}\text { Kelengkapan } \\
\text { Struktur }\end{array}$ & 16 & $55 \%$ & 25 & $86 \%$ \\
\hline $\begin{array}{l}\text { Ejaan dan } \\
\text { Tata Tulis }\end{array}$ & 16 & $55 \%$ & 21 & $72 \%$ \\
\hline
\end{tabular}

Berdasarkan tabel di atas, dapat terlihat peningkatan yang cukup signifikan, pada aspek kesesuaian isi dites awal, nilai rata-rata siswa yang mampu menuliskan paragraf persuasi yaitu sebesar $62 \%$. Sedangkan pada tes akhir sebesar $82 \%$. Pada aspek kelengkapan struktur dites awal, nilai rata-rata siswa yang mampu menuliskan paragraf persuasi dengan struktur yang lengkap yaitu sebesar 55\%, Sedangkan pada tes akhir sebesar 86\%. Pada aspek Ejaan dan tata tulis dites awal, nilai rata-rata siswa yang mampu menuliskan paragraf persuasi dengan struktur yang lengkap yaitu sebesar 55\%, Sedangkan pada tes akhir sebesar $72 \%$.

\section{Uji Hipotesis}

Uji hipotesis dalam penelitian ini dengan menggunakan T-Test untuk mengetahui kemampuan awal sebelum diterapkannya perlakuan dengan kemampuan sesudah diterapkannya perlakuan, dalam uji data T-Test ini peneliti menggunakan SPSS 22 for windows. Adapun kriteria penguji hipotesis adalah jika signifikan $\mathrm{T}$ Test $>$ 0,05 maka Ho diterima dan Hl ditolak. Sedangkan jika signifikan T-Test $<0,05$ maka Ho ditolak dan $\mathrm{H}_{1}$ diterima.

Tabel 9. Paired Samples Statistics

\begin{tabular}{llrrrr}
\hline & & Mean & \multicolumn{1}{c}{ N } & Std. Deviation & Std. Error Mean \\
\hline \multirow{2}{*}{ Pair 1 } & Pre-test & 62.83 & 29 & 11.625 & 2.159 \\
\cline { 2 - 6 } & Post-test & 72.17 & 29 & 9.592 & 1.781 \\
\hline
\end{tabular}

Tabel 10. Paired Samples Correlations

\begin{tabular}{llllll}
\hline & & $\mathrm{N}$ & Correlation & Sig. \\
\hline Pair 1 & Pre-test \& Post-test & & 29 & .835 & .000 \\
\hline
\end{tabular}

Tabel 11. Paired Samples Test

\begin{tabular}{|c|c|c|c|c|c|c|c|c|c|}
\hline & \multicolumn{5}{|c|}{ Paired Differences } & \multirow[b]{4}{*}{$\mathrm{T}$} & \multirow[b]{4}{*}{ df } & \multirow{4}{*}{$\begin{array}{l}\text { Sig. }(2- \\
\text { tailed) }\end{array}$} \\
\hline & & \multirow[b]{3}{*}{ Mean } & \multirow{3}{*}{$\begin{array}{c}\text { Std. } \\
\text { Deviation }\end{array}$} & \multirow{3}{*}{$\begin{array}{l}\text { Std. } \\
\text { Error } \\
\text { Mean }\end{array}$} & \multirow{2}{*}{\multicolumn{2}{|c|}{$\begin{array}{l}95 \% \text { Confidence } \\
\text { Interval of the } \\
\text { Difference }\end{array}$}} & & & \\
\hline & & & & & & & & & \\
\hline & & & & & Lower & Upper & & & \\
\hline air 1 & $\begin{array}{l}\text { Pre-test - } \\
\text { Post-test }\end{array}$ & -9.345 & 6.394 & 1.187 & -11.777 & -6.913 & 7.871 & 28 & .000 \\
\hline
\end{tabular}


Berdasarkan Tabel 9 terlihat bahwa nilai post-test memiliki nilai mean 72,17 dan standar deviasi 9,592. Sedangkan nilai pretest memiliki nilai mean 62,83 dan standar deviasi 11,625. Berdasarkan tabel 11 terlihat bahwa nilai signifikan (2-tailed) dari hasil uji T-Test didapat nilai sebesar 0,000, maka hipotesis Ho ditolak dan hipotesis $\mathrm{H}_{1}$ diterima karena berdasarkan kriteria uji $\mathrm{T}$-Test nilai signifikannya $<0,05$. Jadi dapat ditarik kesimpulan bahwa terdapat pengaruh yang signifikan pada penggunaan media audio visual terhadap keterampilan menulis paragraf persuasi siswa kelas VIII SMPN 3 Cikarang Timur.

Penelitian ini bertujuan untuk mendeskripsikan kemampuan menulis paragraf persuasi tanpa media dengan penerapan media pada siswa Sekolah Menengah Pertama Negeri 3 Cikarang Timur ditinjau dari segi kesesuaian isi, kelengkapan struktur serta ejaan dan tata tulis. Pada kelas VIII.6 Sekolah Menengah Pertama Negeri 3 Cikarang nilai menulis paragraf persuasi masih relatif rendah. Oleh karena itu penulis menggunakan media video untuk dapat melihat perkembangan nilai siswa setelah diterapkannya media tersebut. Berdasarkan penyajian hasil data, dapat diuraikan pada tes akhir yang dilakukan dalam penelitian terjadi peningkatan yang cukup signifikan, menandakan keterampilan menulis persuasi siswa lebih baik dari tes awal. Hal ini menandakan bahwa keberadaan media pembelajaran dapat mempengaruhi kemampuan menulis pada siswa kelas VIII.6 Sekolah Menengah Pertama Negeri 3 Cikarang Timur dalam menulis paragraf persuasi dari segi kesesuaian isi, kelengkapan struktur serta ejaan dan tata tulis. Berdasarkan hasil pengolahan data, tampak bahwa nilai rata-rata tes kemampuan siswa kelas VIII.6 Sekolah Menengah Pertama Negeri 3 Cikarang Timur dalam keterampilan menulis teks persuasi mengalami peningkatan sebanyak 9,34. Nilai rata-rata pada tes awal (pre-test) sebesar 62,83 meningkat menjadi 72,27 pada tes akhir. (post-test). Pada rata-rata tes akhir, siswa memperoleh nilai dengan kategori baik.

Peningkatan yang ditinjau dari aspek kesesuaian isi, pada tes awal nilai rata-rata siswa yang mampu menuliskan paragraf persuasi dengan benar yaitu sebesar $62 \%$. Sedangkan pada tes akhir sebesar $82 \%$. Pada aspek kelengkapan struktur dites awal, nilai rata-rata siswa yang mampu menuliskan paragraf persuasi dengan struktur yang lengkap yaitu sebesar 55\%, Sedangkan pada tes akhir sebesar 86\%. Pada aspek Ejaan dan tata tulis dites awal, nilai rata-rata siswa yang mampu menuliskan paragraf persuasi dengan tanpa kesalahan dalam penulisan yaitu sebesar 55\%, Sedangkan pada tes akhir sebesar $72 \%$. Menurut data tersebut, disimpulkan bahwa media pembelajaran dapat mempengaruhi proses belajar bagi siswa. Jadi, media pembelajaran video iklan layanan masyarakat dapat membuat keterampilan menulis siswa mendapatkan sebuah perubahan yang positif. Penulis setuju bahwa penggunaan media video iklan layanan masyarakat dapat meningkatkan kemampuan menulis paragraf persuasi dan guru dapat menggunakan media ini agar proses pembelajaran lebih bervariatif.

\section{KESIMPULAN}

Berdasarkan hasil penelitian dan pembahasan yang telah dikemukakan sebelumnya tentang penggunaan media iklan layanan masyarakat terhadap keterampilan menulis paragraph persuasi siswa kelas VIII Sekolah Menengah Pertama Negeri 3 Cikarang Timur dapat disimpulkan bahwa 1) Adanya peningkatan nilai rata-rata siswa setelah mendapatkan perlakuan menggunakan media video iklan layanan masyarakat dibandingkan nilai rata-rata sebelum mendapatkan perlakuan menggunakan media video iklan layanan masyarakat. Nilai rata-rata awalnya (pre-test) sebesar 62,83 meningkat menjadi 72,27 (post-test). Selisih kedua rata-rata tersebut yaitu 9,34. 2) Dilihat dari hasil pengujian hipotesis menggunakan SPSS versi 22 menunjukkan bahwa bahwa nilai signifikan (2-tailed) dari hasil uji T-Test didapat nilai sebesar 0,000, maka hipotesis nol Ho ditolak dan hipotesis $\mathrm{H}_{1}$ diterima karena berdasarkan kriteria uji T-Test nilai signifikannya < 0,05. 3) Dari setiap aspek terdapat peningkatan antara nilai pretest dengan posttest. Pada aspek kesesuaian isi dites awal, nilai rata-rata siswa yang mampu menuliskan paragraf persuasi yaitu sebesar $62 \%$. Sedangkan pada tes akhir sebesar $82 \%$. 
2349 Penggunaan Media Video Iklan Layanan Masyarakat di Kanal Youtube terhadap Pembelajaran Menulis Paragraf Persuasi Siswa di Sekolah Menengah Pertama - Elbananda Melati Putri, Wienike Dinar Pratiwi, Een Nurhasanah

DOI: https://doi.org/10.31004/edukatif.v3i4.1183

Pada aspek kelengkapan struktur dites awal, nilai rata-rata siswa yang mampu menuliskan paragraf persuasi dengan struktur yang lengkap yaitu sebesar 55\%, Sedangkan pada tes akhir sebesar 86\%. Pada aspek Ejaan dan tata tulis dites awal, nilai rata-rata siswa yang mampu menuliskan paragraf persuasi dengan struktur yang lengkap yaitu sebesar $55 \%$, Sedangkan pada tes akhir sebesar $72 \%$. Jadi dapat ditarik kesimpulan bahwa terdapat pengaruh yang signifikan pada penggunaan media audio visual terhadap keterampilan menulis paragraf persuasi siswa kelas VIII SMPN 3 Cikarang Timur.

\section{UCAPAN TERIMA KASIH}

Penulis menyampaikan terima kasih sebesar-besarnya kepada dosen pembimbing yang telah memberikan bimbingan serta arahan kepada saya, terima kasih pihak sekolah SMP Negeri 3 Cikarang Timur, kepada keluarga khususnya kedua orang tua yang selalu memberikan doa, semangat serta nasihat-nasihat yang begitu berharga sehingga saya dapat menyelesaikan penelitian ini, dan terakhir kepada teman-teman seperjuangan. Penulis berharap semoga penelitian ini dapat bermanfaat bagi semua pihak yang membacanya. Penulis akhiri dengan mengucapkan terima kasih.

\section{DAFTAR PUSTAKA}

Aliyah, Munifatul. 1994. "Peningkatan Kemampuan Menulis Paragraf Persuasif Melalui Metode Resitasi Dengan Media 'Brosur' Pada Siswa Kelas X-1 Sma Negeri I Rawalo Kecamatan Rawalo Kabupaten Banyumas Tahun Ajaran 20ii/2012.” Repository Universitas Muhammadiyah Purwokerto 5-22.

Astuti, Windi, M. Arifin, And Agus Trianto. N.D. "Perbedaan Kemampuan Menulis Teks Persuasi Menggunakan Media Audio Visual Pada Kelas Viii-A Dan Yang Menggunakan Media Gambar Pada Kelas Viii-B Siswa Smp N 11 Kota Bengkulu.” Jurnal Ilmiah Korpus (1):235-43.

Br. Sebayang, And Theorida Kristina. N.D. "Pengaruh Penggunaan Media Iklan Niaga Terhadap Kemampuan Siswa Menulis Teks Persuasi Di Kelas Viii Smp Negeri 31 Medan Tahun Pembelajaran 2018/2019." Repository Universitas Hkbp Nommensen.

Chaer, Abdul, And Leoni Agustina. 1955. Sosiolinguistik: Suatu Pengantar. Jakarta: Rineka Cipta.

Daryanto. 2013. Media Pembelajaran. Yogyakarta: Gava Media.

Djaali. 2020. Metode Penelitian Kuantitatif. Jakarta: Pt Bumi Aksara.

Famela, Citra. 2014. "Efektivitas Penerapan Media Video Animasi Dalam Pembelajaran Keterampilan Menulis Teks Persuasi Siswa Kelas Viii Mts Al-Muttaqin Plemahan.” Jurnal Penelitian, Pendidikan, Dan Pembelajaran 3-4.

Fitryana, Dewi Ika. 2011. "Peningkatan Keterampilan Menulis Cerpen Melalui Media Berita Dengan Metode Latihan Terbimbing Pada Siswa Kelas X.3 Sma Negeri 1 Rembang Purbalingga."

Mulyani, Riska, And R. Syahrul. 1967. "Pengaruh Model Pembelajaran Kooperatif Tipe Think Talk Write (Ttw) Berbantuan Media Audiovisual Terhadap Keterampilan Menulis Teks Persuasi Siswa Kelas Viii Smp Negeri 8 Padang." Jpbsi (September):5-24.

Nana Sudjana Dan Ahmad Rivai. 2003. Teknologi Pengajaran. Bandung: Cv Sinar Baru.

Nurgiyantoro, B. 2010. Penilaian Pembelajaran Bahasa. Yogyakarta: Bpfe.

Partawan, I. Km Sugi, I. B. Putrayasa, And S. A. Pt Sriasih. N.D. "Menulis Paragraf Persuasi Siswa Kelas X Upw Di Smk Negeri 2 Bangli." Pendidikan Bahasa Dan Sastra Indonesia Undiksha.

Pringgawidagda, Suwarna. 2002. Strategi Penguasaan Berbahasa. Yogyakarta: Adicita Karya Nusa. 
2350 Penggunaan Media Video Iklan Layanan Masyarakat di Kanal Youtube terhadap Pembelajaran Menulis Paragraf Persuasi Siswa di Sekolah Menengah Pertama - Elbananda Melati Putri, Wienike Dinar Pratiwi, Een Nurhasanah

DOI: https://doi.org/10.31004/edukatif.v3i4.1183

Ribawati, Eko. 2015. "Pengaruh Penggunaan Media Video Terhadap Motivasi Dan Hasil Belajar Siswa." Candrasangkala : Jurnal Pendidikan Dan Sejarah 1(1):134-45.

Rusmiyati, Ida, Joko Nurkamto, And Samsi Haryanto. 2014. "Penggunaan Multimedia Dalam Pembelajaran Bahasa Sastra Indonesia Di Smpn 2 Bawen Kabupaten Semarang." Jurnal Teknologi Pendidikan Dan Pembelajaran 2(2):171-84.

Sari, Nautika Narita. 2020. "Penerapan Media Video Iklan Layanan Masyarakat Dalam Pembelajaran Menulis Teks Persuasi Pada Peserta Didik Kelas Viii Smp 2 Kendal Tahun Pelajaran 2018/2019." Seminar Nasional Literasi 68(1).

Sasongko, Ridwan Harnowo, Yulianti, And Karsono. 2008. "Peningkatan Keterampilan Menulis Karangan Persuasi Melalui Penggunaan Media Video."

Sugiyono. 2017. Metode Penelitian Kuantitatif, Kualitatif, Dan R\&D. Ke-26. Bandung: Alfabeta.

Suwandi, Sarwiji. 2018. “Tantangan Mewujudkan Pembelajaran Bahasa Dan Sastra Indonesia Yang Efektif Di Era Revolusi Industri 4.0.” Repository Institusi Kemendikbud 1-20.

Tarigan, Henry Guntur. 2017. Menulis Sebagai Suatu Keterampilan Berbahasa. Bandung: Angkasa. 